\title{
Amide Resonance Structure Detected by NMR to Predict Hydroxyl Unit in Protein
}

\author{
Yan $\mathrm{Jl}^{1, \mathrm{a}, \star}$, Xiao-liang $\mathrm{YANG}^{2}$ and Jun-ming TANG ${ }^{1}$ \\ ${ }^{1}$ School of Chemistry and Chemical Engineering, Henan Normal University, Xinxiang, \\ 453007, China \\ ${ }^{2}$ School of Chemistry and Chemical Engineering, Nanjing University, Nanjing, 210000, \\ China \\ ajiyan98@163.com \\ ${ }^{*}$ Corresponding author
}

Keywords: Amide, Imidic acid, NMR, Protein.

\begin{abstract}
Amide tautomer imidic acid were exit, which proved by NMR spectra characterization. The protein BSA was test by $1 \mathrm{H}$ NMR in different $\mathrm{pH}$ values solutions, to show the different amide/imidic acid structures exit in BSA. The amide/imidic-acid unit with $\mathrm{H}$ proton communication might be the biological protein based information active structures. This paper might to conclude that amide/imidic acid units consist of based information functional active structure units of protein, which will be significant in biological and chemical researches, and will open new times in protein biology.
\end{abstract}

\section{Introduction}

Amide was base group in organic chemistry [1] and biological chemistry [2]. Especially the amide was peptide bond formed protein to be the based units in biological living body, and carry out livings actions. So the amides biological actions were cared and researched since it was found in peptide and protein. Protein was based livings macromolecules, which acting in cells and tissues to carry biological function and to take the biological actions, such as blood red protein, enzyme, muscle protein, serum albumin, and so on.

Protein take very important actions in biological bodies, which have four levels structures based on peptide bond amide connected groups. For example, the bovine serum albumin (BSA) is the important protein in the circulatory system. BSA has 582 amine acid surface groups. serum albumin have lots of physiological function such as maintain the osmotic pressure and $\mathrm{pH}$ of blood [3], and transport a wide variety of endogenous and exogenous compounds including fatty acids, metal, amino acids, steroids and drugs [4]. These extraordinary characteristics of albumins have gained extensive biomedical and chemical applications, which cause the research interest. The human serum albumin (HSA) crystal structure has been determined [5]. Although the conformation of BSA is thought to be similar to HSA due to $76 \%$ of amino acid sequence homology, the three-dimensional structure of BSA has not be characterized. The biological function of a protein depends on its conformation. The most informative method X-ray, NMR, and MS have been used to research BSA. So the peptide bond or amides in BSA in/external body should be characterized by NMR spectra to value the amide actions in protein.

It was should be notified that amide has tautomer, which was imidic acid structure (Scheme 1). The amide resonance structure of imidic acid $(\mathrm{HO}-\mathrm{C}=\mathrm{N})$ has been studied 
during previous experiments [6], and quantum chemical studies [7]. Note that amide and imidic acid are tautomers of each other, and the tautomeric ratios [8] depend on conditions such as the temperature, solvent, and $\mathrm{pH}$. The imidic acid structures have been proved in Polyamidoamine (PAMAM) by 15N NMR, 1H NMR, 13C NMR, and IR spectra [9]. The imidic acid was invested for connecting with the intrinsic fluorescence of polymer PAMAM [10]. The related works show the amide/imidic acid tautomers were transferred at different $\mathrm{pH}$ conditions, which might be connected with $\mathrm{H}$ proton actions. The $\mathrm{H}$ proton transport in peptide and protein have invested by Quantum Chemical Theory method [11], which to predict that $\mathrm{H}$ proton might be conducted in pertide chains to carry some information in protein actions.

This paper used NMR spectra to prove the amide/imidic acid tautomers exited in $\mathrm{N}$-methylacetamide molecule and in protein macromolecule. Based on these $\mathrm{pH}$ dependent NMR, it was tried to deduce that amide/imidic acid tautomers related to biological protein actions.

\section{Results and Discussion}

\section{Materials and Methods}

$\mathrm{N}$-methylacetamide, $\mathrm{NaOD}, \mathrm{P}_{2} \mathrm{O}_{5}$ was purchased from Aladdin Agent Inc. Bovine Serum Albumin (BSA) was purchased from Biotss Biotech Inc. Nuclear Magnetic Resonance (NMR) data were test by 600M BRUCKER NMR spectrometer. The pure $\mathrm{N}$-methylacetamide liquid sample were took NMR firstly. There in $\mathrm{D}_{2} \mathrm{O}$ by adding $\mathrm{NaOD}$ or $\mathrm{P}_{2} \mathrm{O}_{5}$, which aimed to modified the $\mathrm{pH}$ values of NMR samples. The adding of $\mathrm{NaOD}$ kept base condition, and $\mathrm{P}_{2} \mathrm{O}_{5}$ reacted with $\mathrm{D}_{2} \mathrm{O}$ to give $\mathrm{D}_{3} \mathrm{PO}_{4}$ for acid condition. The BSA samples in $\mathrm{D}_{2} \mathrm{O}$ kept as base, neutral, acid conditions were prepared and to take NMR spectra.
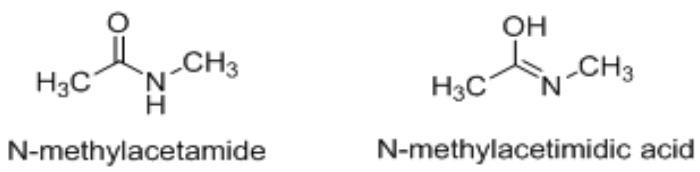

Scheme 1 structure of molecules N-methylacetamide and N-methylacetimidic acid to show the tautomer of amide/imidic-acid.

\section{NMR Structure Characterizations}

$\mathrm{N}$-methylacetamide is secondary amide. The amine acids formed peptide bonds in protein, which are most secondary amide. Therefore using N-methylacetamide to take NMR test can help for protein amide researches.

The 1H NMR spectrum of pure N-methylacetamide liquid gave in Fig. 1. The NMR peak 8.55 ppm was attributed to amide $\mathrm{H}$ connected with $\mathrm{N}$ atom, which was traditional amide $\mathrm{H}$ peak. The multi peaks 2.12 to 2.37 and 2.87 to $3.36 \mathrm{ppm}$ were attributed to two methyl peak. It should be noted the peaks $4.87 \mathrm{ppm}$, which used to be regarded as water before. The Fig. 1 NMR spectrum was pure liquid sample without increase any solvents, so there was no water in sample. Consider the reference 12 , the 4.87 peak should be attributed to hydroxyl structure which might be imidic acid, which $\mathrm{H}$ was connected with $\mathrm{O}$ as $\mathrm{HO}-\mathrm{C}=\mathrm{N}$ peaks.

The Fig. 2 shows the 13C NMR of pure N-methylacetamide liquid sample. The peak $171 \mathrm{ppm}$ was attributed to the amide carbon. The peaks 22.15 and $25.72 \mathrm{ppm}$ were the 
two methyl carbons of N-methylacetamide. The small peak $173.97 \mathrm{ppm}$ should be attributed to carbon of imidic acid, and in respondent to the two methyl carbons peaks of N-methylacetimidic acid that at 19.72 and $29.30 \mathrm{ppm}$. The 1H NMR and 13C NMR of $\mathrm{N}$-methylacetamide can confirm that there exits $\mathrm{N}$-methylacetimidic acid structure in sample. It can be say that amide and imidic acid tautomers co-exit. The ratio of amide/imidic-acid in N-methylacetamide was about 10:1, which got from the H NMR integral areas in Fig. 1.

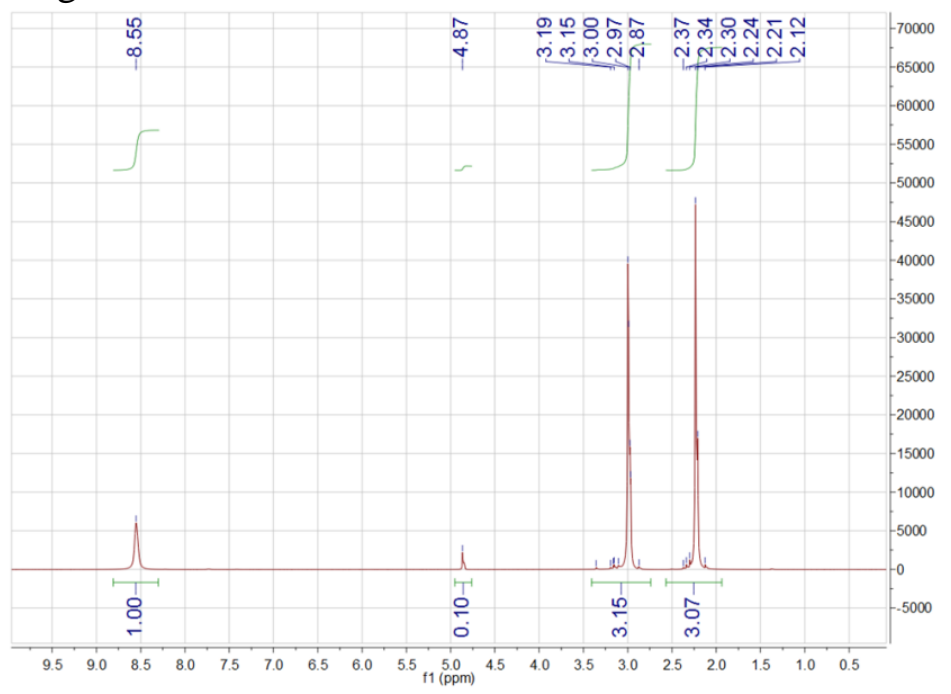

Fig 1. The 1H NMR spectra of pure N-methylacetamide liquid.

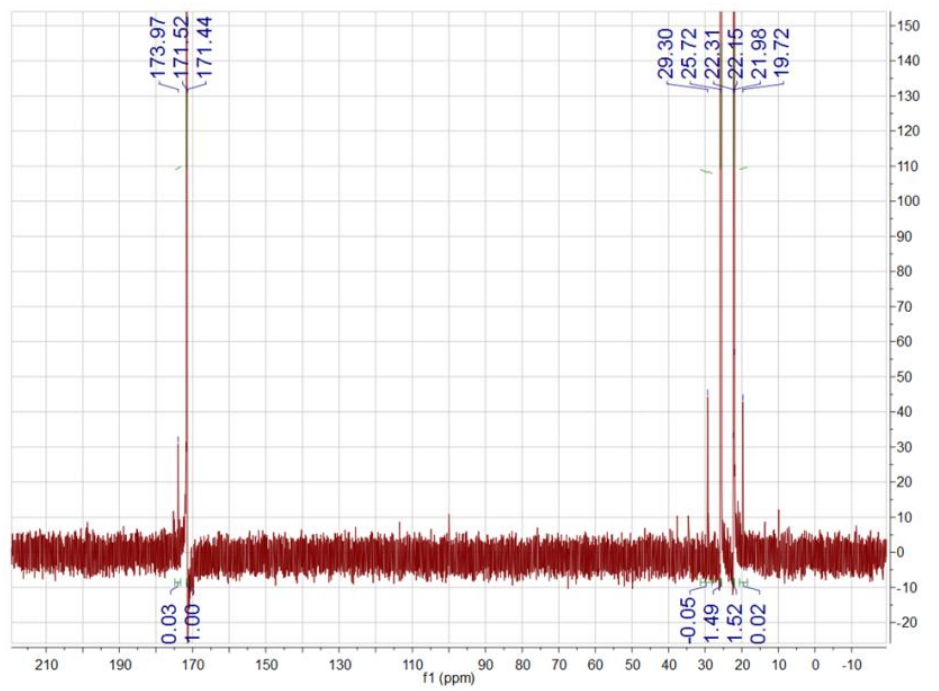

Fig 2. The 13C NMR spectra of pure N-methylacetamide liquid.

\section{H NMR of BSA Protein in Different pH Values}

The NMR method was used to detect the amide structure in BSA protein. NMR can detect not only surface groups, but also the internal $\mathrm{H}$ structures information of protein. Fig.3 show the $1 \mathrm{H}$ NMR spectra of $\mathrm{BSA}$ in $\mathrm{D}_{2} \mathrm{O}$, which $\mathrm{pH}$ was about 7 . There were many multi peaks in Fig. 3, which were display biological information that were unknown and undetermined. The peaks range 6.72 to 7.32 should be attributed to amide $\mathrm{H}$ on $\mathrm{N}$ atom. It were noted that wide peaks $3.83 \mathrm{ppm}$, which should be attributed to imidic acid $\mathrm{H}$ on $\mathrm{O}$ atom. The integral areas amide/ imidic-acid ratio was about 2.93 : 3.20. The BSA has amide groups and imidic acid groups ration near 1:1. 


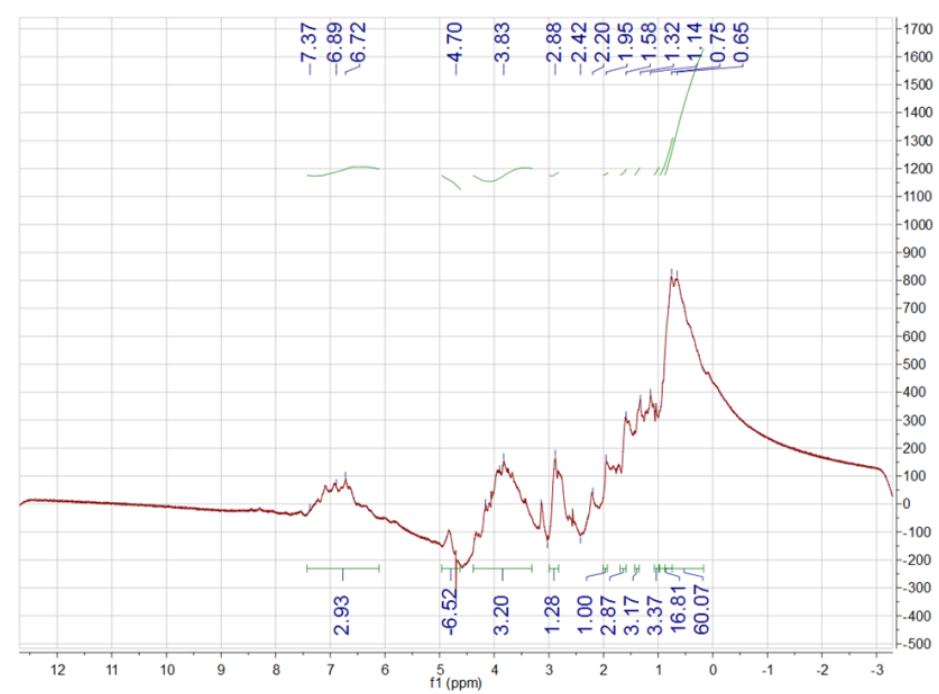

Fig 3. The $1 \mathrm{H}$ NMR spectra of BSA in neutral condition D2O.

Fig 4. Show the $1 \mathrm{H}$ NMR spectra of $\mathrm{BSA}$ in $\mathrm{D}_{2} \mathrm{O}$ by increased base $\mathrm{NaOD}$, which $\mathrm{pH}$ was $>7$. After increased base, the BSA NMR gave sharp peaks; many wide peaks have been disappeared, which mean the biological actions of BSA have been destroyed by strong base NaOD. To compare with the neutral pH Fig. 3, the Fig. 4 at range 6.35 to 7.20 show many sharp peaks, which were attributed to amide groups, and the integral areas were 4.09+1.38+1.11. It was noted in Fig. 4, the peaks range from 3.8 to 4.2 disappear near to zero line with integral area near 1.0, which mean the imidic acid group have been destroyed and transfer to amide type groups. The Fig. 4 might be concluded that imidic acid take many biological actions information that have been destroyed by base $\mathrm{NaOD}$, and imidic acid change into amide type groups. The amide/imidic-acid integral areas might be 6.58/1.0.

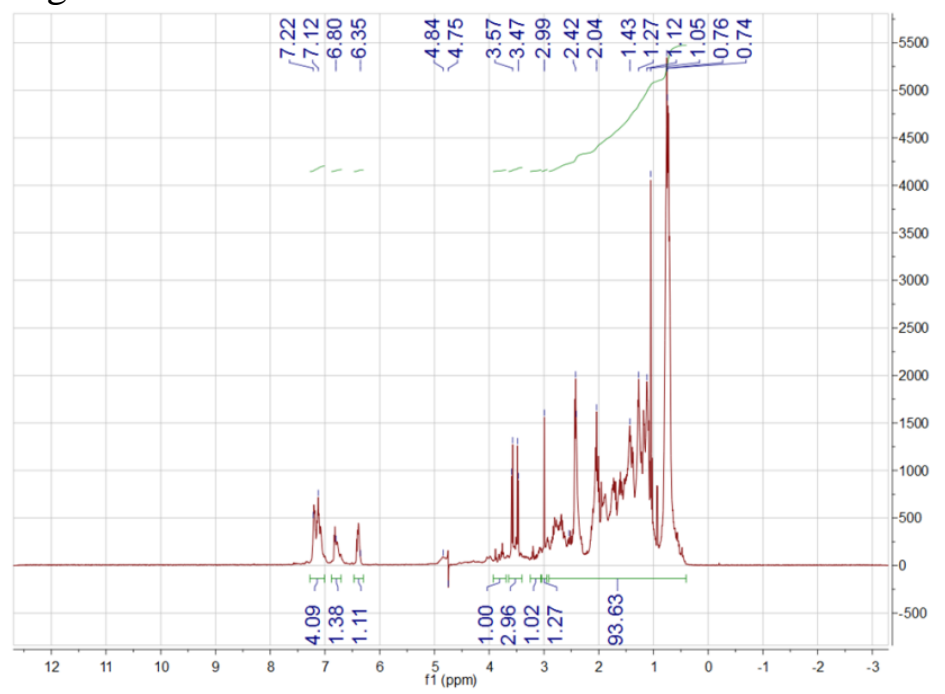

Fig 4. The 1H NMR spectra of BSA in base condition D2O increased with NaOD.

The Fig 5. Showed the $1 \mathrm{H}$ NMR spectra of BSA in $\mathrm{D}_{2} \mathrm{O}$ by increased $\mathrm{P}_{2} \mathrm{O}_{5}$ to take as $\mathrm{D}_{3} \mathrm{PO}_{4}$, which $\mathrm{pH}<7$. The peaks in Fig. 5 kept as some wide peaks, which might mean the $\mathrm{D}_{3} \mathrm{PO}_{4}$ took little destroyed on BSA. The amide peaks $7.26 \mathrm{ppm}$ with integral areas 6.46. The 4.04 wide peaks were the imidic acid peaks, which integral areas 11.96. So the ratio of amide/imidic-acid was about $1: 2$ in acid $\mathrm{pH}$ conditions.

The Fig. 3, 4, 5 show BSA 1H NMR in different $\mathrm{pH}$ conditions, which show the $\mathrm{pH}$ values effect on amide/ imidic-acid ratios. Base increased amide type groups, acid 
increased imidic-acid type groups. It could be concluded that $\mathrm{H}$ proton act on the ratios of amide/imidic-acid, and $\mathrm{H}$ connected with the BSA biological information, by modified the ratios of amide/imidic-acid to effect on the biological actions of BSA. So the $\mathrm{H}$ proton information based on amide/imidic-acid ratios and positions of amide or imidic acid, which formed the BSA protein information edited code units, changed by $\mathrm{H}$ proton conditions.

Exchange $\mathrm{H}$ proton conditions, internal protein $\mathrm{D}$ exchange $\mathrm{HO}-\mathrm{C}=\mathrm{N}$ proton , that were proton information communication channel, D must go through proton channel and then will take proton exchange with $\mathrm{HO}-\mathrm{C}=\mathrm{N}$, under neutrol and acid condition, $\mathrm{D}$ did not gone inti protein and without exchange the $\mathrm{H}$ in $\mathrm{HO}-\mathrm{C}=\mathrm{N}$. While in base condition, the internal protein $\mathrm{HO}-\mathrm{C}=\mathrm{N}$ transfer to amide, to not take $\mathrm{HO}-\mathrm{C}=\mathrm{N}$ proton peaks.

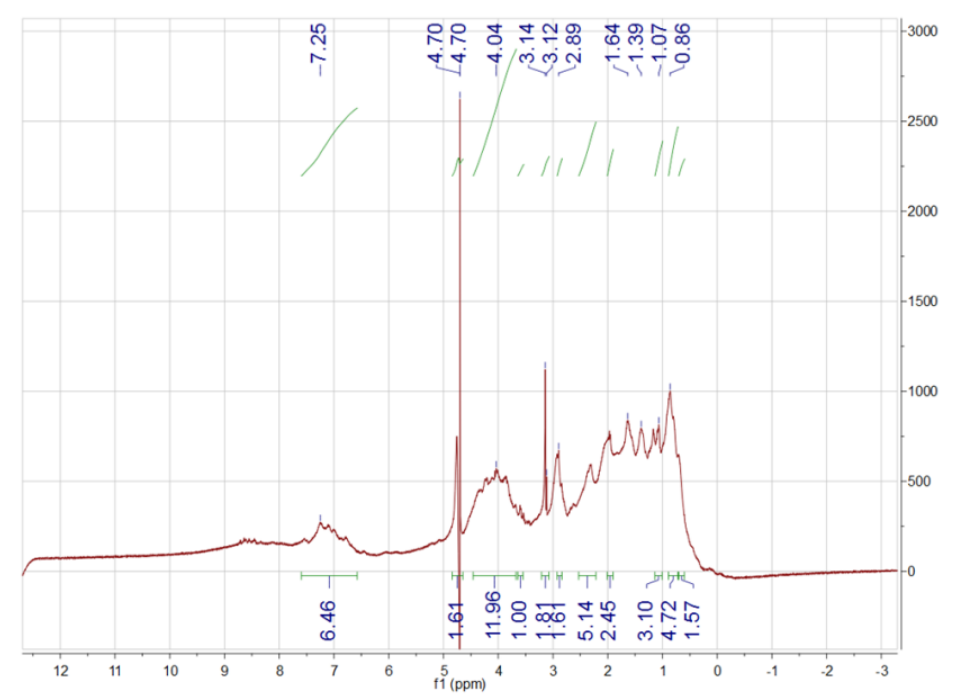

Fig. 5 the 1H NMR spectra of BSA in acid condition D2O increased with P2O5.

\section{Biological Meaning}

Protein was the base biological macromolecules, and take lot of kinds of biological actions. Until now, many protein action mechanisms were still unknown. The protein has four levels structure, which were amine acid form peptide by amide bonds. The amide takes very important actions in protein, while the amide action structure and mechanism were at initial stages. The chemistry method research amide have taken long time, such as the IR spectra of amide take I band, II band, III band character absorption peaks [12]. The IR and NMR can help to release the amide structure to invest the proteins functional active units.

The NMR of N-methylacetamide and BSA protein under different $\mathrm{pH}$ can determine that amide has tautomer imidic acid structure, which transition was connected with $\mathrm{H}$ proton conductions. So the $\mathrm{H}$ proton conduct can change the amide/imidic-acid tautomer ratio, which may be connected with protein active function.

\section{Conclusion}

NMR spectra determined the amide/imidic-acid tautomer exits in N-methylacetamide. The amide/imidic-acid tautomer transition by $\mathrm{H}$ proton transferred and conducted. The 1H NMR of BSA proteins show the amide and imidic acid transition under different $\mathrm{pH}$. In one words, $\mathrm{H}$ proton communication modified the protein information based on amide/imidic-acid tautomer code structure units. This deduction 
might help to explain the protein active function and mechanism. This result that $\mathrm{H}$ proton communication based on amide/imidic-acid tautomer unit will open a new time in protein biology.

\section{Acknowledgement}

Henan Normal University Doctor Project Startup Science Foundations (QD15114).

\section{References}

[1] Carey, F. A. Organic Chemistry, 6th ed.; McGraw Hill: New York, (2006).

[2] Walker, CBE FRSE, Peter M. B., ed. Cambridge Dictionary of Science and Technology (reprint ed.). Edinburgh: Press Syndicate of the University of Cambridge. p. 658. (1990)

[3] D. C. Carter, J. X. Ho, Structure of serum albumin. Adv. Protein Chem. 45(1994) 153

[4] D. C. Carter, X. He, S. H. Munson, P. D. Twigg, K. M. Gernert, M. B. Broom, T. Y. Miller, Three-dimensional structure of human serum albumin. Science, 244 (1989) 1195.

[5] X. M. He, D. C. Carter, Atomic structure and chemistry of human serum albumin. Nature, 358(1992) 209

[6] L. Antonov, Tautomerism: Methods and Theories, Wiley-VCH, Weinheim, 1st edn, (2013);

[7] C. R. Kemnitz and M. J. Loewen, Amide Resonance" Correlates with a Breadth of C- N Rotation Barriers. J. Am. Chem. Soc. 129(2007) 2521-2528.

[8] R. M. Balabin, Tautomeric equilibrium and hydrogen shifts in tetrazole and triazoles: Focal-point analysis and ab initio limit. J. Chem. Phys. 131(2009) 154307.

[9] Y. Ji, X. L. Yang, Y. Qian, Poly-amidoamine structure characterization: amide resonance structure of imidic acid $(\mathrm{HO}-\mathrm{C}=\mathrm{N})$ and tertiary ammonium. $\mathrm{RSC}$ Adv. 4(2014) 49535-49540

[10] Y. Ji, Y. Qian A study using quantum chemical theory methods on the intrinsic fluorescence emission and the possible emission mechanisms of PAMAM. RSC Adv. 4(2014) 58788-58794

[11] J. Dreyer, C.Zhang, E. Ippoliti, P. Carloni, Role of the membrane dipole potential for proton transport in gramicidin A embedded in a DMPC bilayer. J. Chem. Theory Comput.9(2013) 3826-3831

[12] Leif O. Paulson, David T. Anderson, Infrared spectroscopy of the amide I mode of N-methylacetamide in solid hydrogen at 2-4 K. J. Phys. Chem. B 115(2011) 13659-13667 